\title{
CHD8 wt Allele
}

National Cancer Institute

\section{Source}

National Cancer Institute. CHD8 wt Allele. NCI Thesaurus. Code C102441.

Human CHD8 wild-type allele is located in the vicinity of $14 q 11.2$ and is approximately 71 $\mathrm{kb}$ in length. This allele, which encodes chromodomain-helicase-DNA-binding protein 8 , is involved in both transcriptional regulation and chromatin modification. 